comfortable. Even more discomforting is confronting one's own ideas and beliefs. This is not an easy task for any of us (Brookfield 1990, 12-13). It may be even more difficult for our students who come to us as dualistic thinkers (Perry 1970, 59-71) and may lack confidence in their own academic abilities (Brookfield 1990, 44).

Our task is to help students along the path of critical thinking. We do this by being supportive when they venture out and take the risks that critical thinking involves. We let them know that while we place demands on them, we will also be there to provide support if need be (Elbow 1986, 153-59). We understand the process they are going through. Each of us went through our own initial reaching out, and, as role models, we continue to reach out. While as a teacher I can model critical thinking and help guide students, I cannot really do the thinking for them. Ultimately, each of them must make the learning their own.

\section{References}

Andrews, John D. W. 1980. "The Verbal Structure of Teacher Questions: Its Impact on Class Discussion." $P O D$ Quarterly 2: 129-63.

Belenky, Mary Field, Blythe McVicker Clinchy, Nancy Rule Goldberger, and Jill Mattuck Tarule. 1986. Women's Ways of Knowing: The Development of Self, Voice and Mind. New York: Basic Books.

Brookfield, Stephen D. 1987. Developing Critical Thinkers: Challenging Adults to Explore Alternative Ways of Thinking and Acting. San Francisco: Jossey-Bass.

Brookfield, Stephen D. 1990. The Skillful Teacher: On Technique, Trust, and Responsiveness in the Classroom. San Francisco: Jossey-Bass.

Elbow, Peter. 1986. Embracing Contraries: Explorations in Learning and Teaching. New York: Oxford University Press.

Paul, Richard. 1987. "Critical Thinking, Moral Integrity, and Citizenship: Teaching for the Intellectual Virtues." The Seventh Annual and Fifth International Conference on Critical Thinking and Educational Reform, Sonoma State University.

Paul, Richard. 1990. Critical Thinking: What Every Person Needs to Survive in a Rapidly Changing World. Rohnert Park, CA: Center for Critical Thinking and

\title{
Collaborative Education in Taft Seminars Energizes Political Science Education of Teachers
}

\author{
Mary A. Hepburn, University of Georgia
}

\begin{abstract}
"I am amazed at the amount I have learned about our system and the depth to which I now can explore this topic. I'm now curious and excited to learn more. I'm also more confident about the system than I was before," wrote a North Carolina teacher who in the summer of 1992 had attended a Taft Seminar. This teacher's reaction to the intensive two-week course on American politics and government is but one of thousands of enthusiastic, affirmative evaluations of Taft Seminars for Teachers in the 32 years that they have been offered.

Professors who direct and teach in the seminars, which are conducted on college campuses around the country, are similarly enthusiastic
\end{abstract}

about this special course for teachers. A political scientist reviewing the summer seminar on his northeastern college campus recently wrote, "The opportunity to interact with highly qualified and dedicated professionals from the public sector provides the Seminar participants with learning opportunities unmatched in other programs." Another professor reviewing the Taft Seminar approach wrote, "I know of no other teacher program that provides this rich blend of the theoretical and practical. I have heard many teachers praise the experience as the best teacher education course they have ever taken."

The Taft Seminars are by design educational collaboratives, bringing together professionals representing
Moral Critique.

Perry, William G., Jr. 1970. Forms of Intellectual and Ethical Development in the College Years. New York: Holt, Rinehart and Winston.

Siegel, Harvey. 1988. Educating Reason: Rationality, Critical Thinking and Education. London: Routledge.

Taylor, William. 1991. "Socratic Questioning as a Tool for Teaching Critical Thinking." Midwest Political Science Association Annual Meeting, Chicago, April 19.

\section{About the Author \\ Mel Cohen is an associate professor at Miami University Middletown, where he teaches in a number of fields, including American politics, public administration, and comparative politics.}

diverse educational and political institutions to examine political processes and contemplate how to better educate students about these processes. The seminars were initiated by the Taft Institute, a leading national civic education organization, as a means to improve the academic background of social studies teachers in American government and politics. Through grants to co-sponsoring institutions, the Institute covers almost all of the teachers' expenses for the program, including tuition for graduate credit. The Institute also provides room and board for teachers who do not live within commuting range of the host institution.

School boards, parents, and the society at large generally assign 
schools and teachers the responsibility of educating students to become participants in the democratic political system. However, teachers who have the professional responsibility for educating young people about government and politics have few opportunities or incentives in regular graduate programs to take more than one or two courses in the subject. As a result, very few have studied political science in any depth since their undergraduate years. To remedy this deficiency, Taft immerses teachers for two weeks in the theory and practice of American politics, using recent research, a variety of teachinglearning formats, and a highly participatory approach.

The collaborative mode of planning and achieving educational improvement has gained prominence in current research and advocacy literature on higher education. In recent years a number of projects have been launched to overcome the traditional isolation of subject matter instruction from the pedagogical preparation of teachers. But this concern is not new to the Taft Seminars. Since the mid-sixties, they have employed cross-disciplinary alliances and combined instruction by academicians and political practitioners in order to enrich learning and better serve teachers.

\section{The Collaborative Model for Continuing Teacher Education}

While professors complain about the lack of preparedness of freshmen entering college, teachers protest that they are assigned to teach courses for which they have only minimal resources and academic preparation. Collaborative courses provide professors and teachers a means to jointly address these problems by strengthening learning in a specified subject discipline or in several disciplines with research related to a specific academic question. Generally, college-school collaboratives try to bridge the cultural gulf between higher education and school education to advance the common goal of improving academic preparation of the nation's youth.

Institutional Effects. Collaborative courses help to promote open and beneficial communication across dif- ferent institutional settings involved in different levels of the same educational endeavor - the transfer and analysis of knowledge and reflection on its implications for society. Collaborative courses at the graduate level help reduce the fragmentation in a teacher's advanced education. Such fragmentation is especially evident in larger institutions of higher education where teachers may take graduate course work from professors in two or three colleges. The arts and science professors may have little or no awareness of the needs of

\section{The Taft Seminars are by design educational collaboratives, bringing together professionals representing diverse educational and political institutions to examine political processes and contemplate how to better educate students about}

these processes.

teachers and schools, and they may seldom or never communicate with colleagues in university education departments or with school teachers. Likewise, the education specialists may have little awareness of developments in arts and science disciplines. Hence, while collaborative courses provide teachers with research updates and current perspectives in a subject, the experience also generates cross-departmental communication in higher education. In turn, it gives academicians insights into current issues of pre-collegiate education and the general social and political milieu of the schools in which teachers work (Grossman et al. 1989; McCormick 1990).

Personal-Professional Gains. By helping to narrow the distance between universities and schools, collaborative courses help to break down perceptual walls that have formed between academic subject matter and practical teacher prepara- tion, thus encouraging teachers and professors from several disciplines to exchange information and views. Teachers gain a professional connection to the college professors who are the researchers of their school subject's discipline. Both professors and teachers have opportunities to know each other as individuals concerned about some of the same issues in our society. (See Merklin 1989 and Engelhardt 1991.)

Typically, college-school educational collaboratives bring together professionals from institutions with different cultures, operating with different reward systems, and with different ideas about professional achievement. Ideally, as the group focuses attention on specific substantive material and specific issues of teaching about that material, academic and practical expertise become allied in working for educational advancement. Professors and teachers are involved in a two-way communication process that connects teachers to newer constructs, recent scholarship, theoretical developments, and varying viewpoints in the subject discipline. In return, college professors in the collaborative gain an awareness of the realities of the classroom and the community wherein the subject matter is taught. (See for examples, Watkins 1989; Brookhart and Loadman 1990; Gaudiani 1990.)

Accordingly, in the political science discipline, collaborative programs bring higher education professionals and school professionals together to examine selected recent scholarship and issues and to discuss means to improve teaching about government and politics. The American Political Science Association has been a leader in a number of collaborative education programs over the years (Hepburn 1987). Most recently, APSA has been working with the American Historical Association to sponsor several types of educational improvement projects for teachers and schools through The Bill of Rights Education Collaborative. 


\section{Taft Seminars: Educational Collaboratives in Political Science}

The Taft Seminars utilize this kind of professor-teacher connection and college-school linkage annually, and, in addition, provide a unique collaborative dimension, in that they always include political practitioners as instructors. Elected and appointed government officials from national, state, and local levels; campaign workers; media political analysts; and party leaders are among the practitioners who as guest instructors offer pragmatic insights into the workings of government. Directors strive to keep a balance in the partisan affiliations of guest instructors and to give broad and fair representation of viewpoints on public issues.

The success of political science education collaboratives, like other collaborative education efforts, depends primarily on whether the cross-professional group can overcome sharply different role perceptions and begin to work together to change educational practices. This requires breaking down stereotypes of professors, teachers, and politicians through many hours of open communication and interaction. Likewise, it requires mutual respect.

The emphasis on collegiality and mutual respect between teachers and professors not only strengthens learning experiences in the course, but also encourages the scholarly professional development of teachers, enhancing their self-confidence and empowering them in their school settings. In many cases the Taft Seminars have had a continuing outreach to the schools extending far beyond the two-week seminar on campus to specific educational projects in school districts. The common interest in political science education established during and following Taft Seminars may eventually have influences on the state curriculum and on educational decision making in the state. Similarly, the alliances formed in a Taft Seminar may lead to the development of educational media and curriculum materials that are used to enrich the study of political science in the schools.

Interviews. College professors who serve as directors and key instructors in Taft Seminars attest to these academic and practical benefits of the course. For example, Donald Alper and Eugene Hogan, co-directors of the course at Western Washington University, explain, "The mystique of the Taft Seminar is no mystery. Teachers are recognized and treated with respect: that is, respect for them as persons, for their intellectual accomplishment and for the job they do. Taft Seminars and Taft directors manifest this respect in the thought and preparation that goes into the required readings and in the challeng-

Typically, college-school
educational collaboratives
bring together
professionals from
institutions with different
cultures, operating with
different reward systems,
and with different ideas
about professional
achievement.

ing and demanding programs that are offered. Teachers put more into Taft because more is expected of them. Taft Institute scholarships make the teachers feel special."

Bruce Rogers, political science professor at Tennessee State University, further explains, "Treating teachers like the professionals they are reaps untold rewards in the classroom. Most teachers have never been in a professional situation where they have been made to feel like valued and valuable professionals. ... For instance, the Taft Seminar places Taft Teacher Fellows into the context of politics. They meet one-on-one with political actors, and some teachers begin to view themselves in political roles that they never thought possible before the course. . . . A large part of the success of the Taft Seminars is due to the commitment of the practicing politicians, lobbyists, and others to 'tell it like it is.' I never cease to be amazed at the frankness with which almost all of the lecturers approach the seminar. They seem to welcome the opportunity to talk frankly, honestly, with no holds barred-in the absence of reporters."

Jewel Prestage, a political scientist who has co-directed many Taft Seminars at Southern University, corroborates the importance of mutual respect: "In the Southern University program the teacher-participant is made to understand that the Seminar is a joint effort by professionals at the precollegiate level and the university level designed to upgrade political education in the nation's schools. The centrality of the classroom teacher in the educational process is stressed as is the role of the teacher as a professional with extra-classroom responsibilities as a citizen."

Jerry Moore, who has directed numerous Taft Seminars at the University of Virginia, describes the statewide effects of teacherprofessor-practitioner involvement in improving political education. "Ripple effects from our seminars have been the basis for in-service networking throughout the Commonwealth of Virginia on the teaching of government and politics. A project entitled "The Teacher Resource Service" (for government and social studies teachers) was developed eight years ago in our Center for Public Service to provide teachers with new, in-depth resources on teaching state and local government. Every one of the teachers selected to direct the project has been a Taft Fellow. Paralleling the experience in the Taft Seminar, they have planned and directed seminars in the state capitol. Taft graduates have also gone on to provide educational and political leadership in the Virginia Law Project and the Virginia Council for the Social Studies, and others have been elected to public office."

At the University of Georgia, the author has seen similar effects from the Taft Seminar over the last decade. Many of the Taft Seminar graduates are now supervisors and department heads, positions in which they can shape, review, and directly influence decisions regarding education in the schools. A number of the teachers have run for state and local government offices, and several have 
been elected. They all credit the summer experience in the Taft Seminar as playing a key role in their professional growth and civic activism.

Victor Profughi, professor of political science at Rhode Island College, speaks about the practical, professional outcomes sought for his seminar. "Teachers are required to complete a series of readings of materials distributed about a month in advance of the opening class. They attend all sessions and take part in discussion. In addition, each student prepares an instructional unit utilizing effective approaches to secondary or elementary teaching. These materials are then shared with all seminar participants."

Profughi's emphasis on practical application is illustrated by his selection of Claude Gladu as assistant director. Gladu, a member of the political science faculty, is a former high school teacher and also serves as an instructor in the college's Social Studies Practicum Program.

In addition, Profughi is one of a number of Taft directors now implementing follow-up sessions during the academic year in order to assess the impact of the Taft Seminar program. His follow-up activities during the 1992-93 school year included a mail questionnaire to recent Taft Fellows, classroom visitations based on questionnaire responses, selection of "Master Teachers" based on excellence in classroom teaching, and an all-day follow-up session devoted to political information updates, model presentations by Master Teachers, and opportunities to share teaching ideas.

At the University of Montana, political science professor James Lopach has designed a Taft Seminar for the teachers of American Indian youth. The course provides a solid grounding in tribal government, Indian law, and American Indian policy, as well as discussion of contemporary Native American political issues to enrich the study of American government and politics. The rationale was explained by Professor Lopach: "The seminar was based on three considerations. First, there is a close link between the terrible plight of American Indians today and decades of public political decisions. (This is the beginning point of any
Taft Seminar: Politics affects our lives in a profound way.) Second, Indian youth face tremendous hardships in the form of physical and emotional health, quality of education, and economic opportunity. Their condition begs a special response from educators. Third, the national government's contemporary push for tribal self-government and self-determination means that politics is increasingly seen by tribal insiders as part of the solution to reservation problems."

These are but a few examples of

In the Southern University program the teacherparticipant is made to understand that the Seminar is a joint effort by professionals at the precollegiate level and the university level designed

\section{to upgrade political education in the nation's \\ schools.}

the many Taft Seminar collaboratives that have brought teachers, professors, and political practitioners together to strengthen political science education in the schools. Each seminar group works on some kind of instructional improvement. Many develop teaching units grounded in the substance of the seminar, new instructional plans that focus on public issues, and lessons based on classroom discussions with government and party officials. Evaluations by the teachers, including unsigned reviews and formal assessments, give overwhelming testimony that the summer seminars respond to their interests and needs both intellectually and practically.

The number of Taft Seminars each year varies depending on annual fund raising. This summer there will be 14 seminars held on university campuses across the country. A listing is found at the end of this article.
Conclusion. Social studies teachers today confront high levels of cynicism and political alienation in their government classes. To succeed in preparing American youth for responsible citizenship in this challenging environment, they must draw on not only historical and scientific information, but also the personal experiences of people in all levels of political inquiry and participation. These collaborative education courses help them do just that.

From the political scientist's point of view the collaborative may also be a source of empowerment. Wray (1991) has noted a disturbing lack of input by political scientists into the debates on educational reform. As evidenced by Taft Seminars, political education collaboratives also offer a forum on educational policy and one way in which political scientists can make a difference in education.

\section{References}

Brookhart, Susan M., and William E. Loadman. 1990. "School-University Collaboration: Different Workplace Cultures." Contemporary Education 61: 125-28.

Engelhardt, Jon. 1991. "Group Aims to Link Arts and Sciences With Teacher Education." Education Week 11: 6-7.

Gaudiani, Claire L. 1990. "Critical Connection: School/College Faculty Alliances." Thought and Action 6 (May).

Grossman, Pamela L., Suzanne M. Wilson, and Lee S. Shulman. 1989. "Teachers of Substance: Subject Matter Knowledge for Teaching." Knowledge Base for the Beginning Teacher, ed. Maynard C. Reynolds. New York: Pergamon Press, Chapter 3: 23-36.

Hepburn, Mary A. 1987. "Improving Political Science Education in the Schools: College-School Connections."' PS: Political Science \& Politics 20: 691-97.

McCormick, Theresa E. 1990. "Collaboration Works Preparing Teachers for Urban Realities." Contemporary Education 61: 129-34.

Merklin, Marjorie. 1989. "Partners in Learning." The College Board Review 153: 26-33, 53-54.

Watkins, Beverly T. 1989. "Movement to Create 'Academic Alliances' of Teachers of Same Subject at All Education Levels Is Growing." The Chronicle of Higher Education 35: A23-24.

Wray, J. Harry. 1991. "Schools and Politics: A Review Essay." Western Political Quarterly 44: 762-80. 


\section{About the Author}

Mary Hepburn is professor of social science education and head of the Citizen Education Division of the Carl Vinson Institute of Government. She designs, directs, and teaches in collaborative short courses and graduate seminars for teachers on government, politics, and public policy issues. She is currently serving on the Governing Board of the Bill of Rights Education Collaborative organized by APSA and the American Historical Association.

\section{Taft Seminars for Teachers}

\author{
Teaching Citizenship in Urban \\ Classrooms \\ Loyola University Chicago \\ Chicago, IL 60626 \\ Director: Dr. Alan Gitelson, \\ (312) 508-3065 \\ Dates: July 6-17, 1993
}

Designed especially for Chicago-area teachers, this seminar combines an intensive examination of American government and politics with a minority studies component examining issues related to teaching and learning about government and politics in racially and ethnically diverse urban classrooms. Special sessions will help participants understand the historical and cultural differences among minority groups in Chicago, the development of effective curricula for minoritypopulated schools, and ways to encourage minority student participation in the political process.

\section{Political Participation}

Eagleton Institute of Politics

Rutgers University

New Brunswick, NJ 08901

Director: Dr. Gerald Pomper, (908) 932-9384

Dates: July 12-23, 1993

The overall theme of this new seminar will be the varieties of political participation in the United States, from voting to grass-roots community organization to running for political office. In addition to academic study, dialogue with political practitioners, and field trips, emphasis will be placed on classroom application of knowledge, materials, and methods acquired in the program.

American Indians, American Politics

The University of Montana

Missoula, MT 59812-1340

Director: Dr. James Lopach, (406) 243-5054

Dates: June 14-25, 1993

This popular seminar, now in its second year, will explore American poli- tics and its relationship to tribal government and Indian law. Faculty will include Indian political leaders from area reservations. Designed for teachers who work with Native American children, the program will include special sessions on American Indian policy, Indian heroes, and teaching the Indian student.

\section{American Politics:}

A Tapestry of Many Stories

University of Wisconsin-River Falls

River Falls, WI 54022

Director: Dr. Jan Hillard, (715) 425-3318

Dates: July 12-23, 1993

Minnesota and Wisconsin educators will have a unique opportunity to examine, not only the principles, institutions, and processes that constitute our political system, but also some of the unique experiences and diverse stories that create the "tapestry" of American politics. Special attention will be placed on the political culture, status, and experiences of American Indians and Asians living in the upper Midwest. A strong emphasis will be placed on integrating these stories into the social studies curriculum.

An American Apartheid:

The Navajos of San Juan County

Hinckley Institute of Politics

The University of Utah

Salt Lake City, UT 84112

Director: Hon. Ted Wilson, (801) 581-8501

Dates: June 14-25, 1993

Beginning with the struggle of the Navajos of San Juan County, Utah, for full and equal participation in the political process, this course will expand to a comprehensive examination of contemporary American politics and our unfinished national agenda. Educators will visit the Navajo reservation in San Juan County, stay in Navajo homes, and participate in a service project to learn the value of teaching through service.

\section{Democracy and High Tech Politics \\ Western Washington University \\ Bellingham, WA $98225-9082$ \\ Directors: Dr. Gene Hogan and Dr. \\ Donald Alper, (206) 650-4872 \\ Dates: June 27-July 9, 1993}

This year's Pacific Northwest seminar will examine the constitutional and institutional framework of American democracy. Special emphasis will be placed on the "new campaign technology," the influence of polling, political consultants, and media in modern politics, and the challenge this presents to democratic citizenship and representative government in the United States.
Government and Politics in the United States and Germany:

\section{A Comparison}

University of Georgia

Vinson Institute of Government

Athens, GA 30602-5482

Director: Dr. Mary Hepburn,

(706) $542-2736$

Dates: June 23-July 7, 1993

This special cross-national seminar for American and German teachers will be held at the Vinson Institute and the Carter Library in Atlanta. Participants will learn about German Basic Law and how it compares with the U.S. Constitution. They will also examine the institutions and processes of government in the two countries, as well as development of the European Community and its political and economic implications. A comparison of the context in which social studies is taught in Germany and the United States and a review of teaching strategies and instructional materials will also be included.

\section{Taft Honors Seminars}

on National Political Institutions

The Catholic University of America

Washington, DC 20064

Directors: Dr. John Kenneth White and

Dr. Paul S. Herrnson, (202) 319-5128

Dates: June 13-25, 1993

The new Taft Honors Seminar will examine American politics at the national level, with special emphasis on the roles of national political institutions (i.e., the presidency, Congress, Supreme Court), as well as political parties and interest groups. Prominent national leaders will participate in seminar sessions, which will be supplemented by field trips to key governmental institutions and agencies. In addition, special workshops will assist participants in improving their presentation skills and effectiveness as in-service trainers and classroom teachers. Outstanding graduates of previous Taft Seminars and other secondary teachers with exemplary academic, teaching, and public service records are invited to apply.

The Dynamics of North Carolina Politics The University of North Carolina at Charlotte

Charlotte, NC

Director: Dr. Schley Lyons,

(704) $547-2247$

Dates: June 14-25, 1993

Now in its 23rd year, this popular seminar will examine current trends in North Carolina politics, including: the decline in party loyalty among voters, the increase in split-ticket voting and candidate-oriented campaigns, the enhanced role of political action committees in funding campaigns, the proliferation of 
single-issue interest groups, and the professionalization of campaign staffs. Speakers and participants will also explore the changing role of minorities, particularly African Americans, in North Carolina politics.

The New Majority

Xavier University

Cincinnati, OH 45207

Director: Dr. Neil Heighberger,

(513) 745-3601

Dates: June 14-25, 1993

The Xavier seminar will examine the potential emergence of a new majority in American politics from two perspectives: first, the efforts of the new administration to fashion a new electoral, as well as legislative, majority in support of its agenda; and, second, the demographic trends that are literally changing the face of America and the definition of "majority." In particular, the course will focus on political and educational issues related to the largest minorities in the Cincinnati area: African Americans and Appalachians.

Building on the Momentum

Rhode Island College

Providence, RI 02908

Director: Dr. Victor Profughi, (401) 456-8056

Dates: June 21-July 2, 1993

While the 1992 election sparked increased interest and participation in the political process, will there be a lasting impact? Was the surge in citizen involvement a temporary phenomenon or the beginning of a new era? How can minorities, particularly immigrants, be encouraged to become active, informed citizens? Participants in the Rhode Island seminar will explore these and other questions through dialogue with some of the key actors in politics and government at the local, state, and national levels.

\section{Governmental Transitions:}

The Changing of the Guard

Tennessee State University

Nashville, TN 37209-1561

Director: Dr. Bruce Rogers, (615) 320-3015

Dates: June 14-25, 1993

The focus of this year's Tennessee seminar will be the transition between political campaigns and operational governments. How do campaign teams reorganize to form a new government? What conflicts arise in the shift from purely political activities to the more regularized activities of managing a government? Members of the Clinton-Gore transition team, and their counterparts at the local and state levels, will serve as guest faculty and provide an intimate look at the changing of the guard in American politics.
American Politics: A Study in Cultural and Political Diversity Southern University

Baton Rouge, LA 70813

Director: Dr. Jewel Prestage

Assistant Director: Dr. James Llorens, (504) $771-3210$

Dates: July 6-17, 1993

Now in its third year, the Southern University seminar will examine American historical and political development with special emphasis on the distinctive political cultue of Louisiana. Participants will review recent research on the political socialization and cognitive learning styles of minority children, as well as materials and methods to help them meet the challenge of classroom diversity.

Contemporary Government and Politics in Connecticut

Institute of Public Service

University of Connecticut

Storrs, CT 06269-4014

(203) 486-2828

Director: Dr. Edward C. Sembor

Dates: August 2-13, 1993

This new seminar, to be conducted on the West Hartford campus, will give teachers a better understanding of the American political system, with special emphasis on state and local government in Connecticut, citizenship education, and current urban public policy issues. Participants will receive assistance in applying new knowledge, methods, and materials in the classroom and will return for a one-day follow-up session during the 1993-94 school year.

\title{
Bringing Law to Bear on International Relations Theory Courses*
}

\author{
Nicholas G. Onuf, The American University \\ James Larry Taulbee, Emory University
}

\begin{abstract}
As an area of serious study, international law has all but disappeared from the contemporary curricula of political science and international relations (IR) in the United States. Basic courses in international relations at the undergraduate level give fleeting attention to international law, reflecting both the attitudes of instructors and the desultory and antiquated treatment in most basic textbooks (Taulbee 1988). Many undergraduate curricula still sport an upper division course, for which pre-
\end{abstract}

law majors serve as a reliable constituency, but upon close examination these courses often prove to be anomalies, rather than a core part of an integrated plan of study. This observation holds particularly for curricula that purport to offer a concentration in international relations, international studies, or some similar variant.

At the graduate level, the decline of international law as primary focus of graduate instruction is even more evident. Professional schools of international affairs often, but not uniformly, offer courses-sometimes several. As suits the vocational thrust of such schools (indicated by the term "affairs"), these courses typically use the casebook method preferred for legal instruction in the United States. Few departments of political science now offer a graduate course in international law because few have faculty competent to teach it. By itself, the absence of competent faculty forms a devastating commentary on how the discipline in 